\title{
PENGARUH PELATIHAN DAN KALIMAT MOTIVASI TERHADAP PRODUKTIFITAS KERJA KARYAWAN UMKM
}

\author{
Sri Andika Putri ${ }^{1}$ dan Warianto ${ }^{2}$ \\ Universitas Tribhuwana Tunggadewi Malang \\ Email: sriandika66@gmail.com
}

\begin{abstract}
ABSTRAK
Usaha mikro kecil menengah (UMKM) sangat berperan penting dalam perkembangan ekonomi Indonesia dan diharapkan dapat menyerap tenaga kerja sehingga mengurangi penganguran yang ada di Indonesia. Keberadaan UMKM sudah tidak diragukan lagi karena mampu bertahan dan menjadi penggerak ekonomi masyarakat Indonesia. Pelaksanaan aktifitas-aktifitas bidang tersebut harus didukung dengan adanya pelatihan dan motivasi agar dapat meningkatkan produktifitas kerja seseorang maupun karyawan yang bekerja dibagian tersebut. Hal tersebut dilakukan dalam usaha memecahkan berbagai permasalahan yang dihadapi dengan cara meningkatkan dan memperdayakan berbagai usaha dibidang UMKM yang keberadaannya sangat berpengaruh didalam kemajuan ekonomi Indonesia.

Tujuan penelitian ini adalah untuk menganalisis pengaruh pelatihan dan kalimatkalimat motivasi yang digunakan oleh pemilik UMKM terhadap karyawan sehingga karyawan memiliki produktifitas kerja yang tinggi. Penelitian dilakukan di UMKM NEES Tailor dan Konveksi yang ada di Kota Malang. Metode penelitian yang digunakan adalah kuantitatif. Sistem pengumpulan data dilakukan secara mengobservasi lapangan, mendokumentasi, dan mewawancarai pemilik dan karyawan UMKM.

Dari penelitian yang telah dilakukan diperoleh beberapa kesimpulan yaitu pelatihan yang telah diberikan berupa pelatihan tentang tata cara menyablon dan menjahit baju berpengaruh positif terhadap produktifitas kerja karyawan dan kalimat motivasi yang dilontarkan berpengaruh positif juga terhadap produktifitas kerja karyawan. Pekerjaan karyawan dari hari ke hari menjadi semakin baik dan karyawan merasa puas dengan penghargaan yang diberikan, baik berupa benda maupun kalimat pujian.

Kata kunci : Pelatihan, Kalimat Motivasi, Produktifita
\end{abstract}




\section{PENDAHULUAN}

Hakikakatnya pembangunan yang telah dan akan di laksanakan oleh pemerintah merupakan suatu rangkaian menuju kemajuan yang diharapkan agar negara menjadi lebih baik. Perubahanperubahan yang dilaksanakan bukan hanya bersifat nyata dalam bentuk fisik, tetapi juga menyangkut perubahanperubahan yang dilaksanakan melalui sikap, prilaku dan nilai-nilai dalam kehidupan masyarakat.

Seiring dengan perkembangan teknologi yang semakin maju, maka sistem perdagangan juga mengalami perubahan. Hal ini memicu para produsen untuk meningkatkan kreatifvitas dan produktivitas agar bertahan menghadapi perubahan pasar.

UMKM merupakan salah satu strategi pemasaran yang dikembangkan oleh pemerintah untuk membantu perekonomian masyarakat. Dengan meningkatnya UMKM maka perputaran perekonomian Indonesia tidak menjadi persoalan sebab ia menyerap tenaga kerja dan tingkat pengangguran menjadi berkurang bahkan ada kemungkinan menjadi tidak ada.

Keberadaan UMKM tidak perlu diragukan karena terbukti mampu bertahan dan menjadi pengerak ekonomi, terutama setelah krisis ekonomi. UMKM juga dinyatakan banyak menghadapi masalah keterbatasan modal kerja,sumber daya manusia yang rendah,dan kurangnya ilmu pengetahuan dan teknologi (Sudaryanto dan Hanim, 2002).

Tahun 2016 kita dihadapkan dengan MEA. Dengan demikian, Pemerintah Propinsi Jawa Timur harus sudah mempunyai strategi dalam menghadapi masyarakat ekonomi ASEAN pada tahun 2016. Gubernur Jawa Timur, Soekarwo, menyampaikan beberapa langkah strategi yang dilakukan oleh pemerintah diantaranya dengan melakukan pembinaan kepada sentra usaha mikro kecil dan menengah atau UMKM. Pelatihan dan sosialisasi juga dilakukan mengingat pentingnya tampilan produk atau packaging agar tampilan menarik dan diterima di pasar ASEAN 2016.

Ditengah arus globalisasi dan tingginya persaingan sehinnga diperlukan pemberdayaan UMKM yang sanggat penting dalam menghadapi tantangan global, seperti berinovasi dalam meningkatkan produk atau jasa yang dihasilkan, pengembangan sumber 
daya manusia dan teknologi, serta memperluas area pemasaran.

Dengan demikian diperlukannya pelatihan untuk meningkatkan suatu produktifitas seseorang dalam menciptakan produk-produk yang mampu bersaing didunia internasional. Kalimat motivasi merupakan salah satu dorongan secara psikologis yang sangat berperan penting dalam meningkatkan suatu kepribadian yang baik dalam melaksanakan suatu pekerjaannya. Dengan adanya dua bentuk perlakuan tersebut maka diharapkan dapat mendorong seseorang lebih meningkatkan produktivitas kerjanya.

Menurut Sunarto (2005:p13) motivasi dapat dikatakan sebagai perilaku yang beriorentasi tujuan. Memotivasi ialah mengajak karyawan agar ikut dalam menyelesaikan tugas atau tanggung jawab yang telah diberikan.

Selain itu pemberian pelatihan sangat lah penting dalam meningkatkan pengalaman kerja karyawan sehingga mampu menciptakan produk-produk yang berkualitas dan mampu bersaing dengan produk-produk yang ada di pasar. pengetahuan atau keterampilan yang sudah dikuasai seseorang sebagai akibat perbuatan atau pekerjaan yang telah dilakukan sebelumnya selama jangka waktu tertentu.

Produktivitas adalah suatu sikap mental seseorang yang memiliki pemikiran tentang perubahan yang lebih baik dari sebelumnya, dan hari esok harus lebih baik dari pada hari ini. Sikap-sikap yang produktifitas dapat menimbulkan hal seperti, sikap motivatif, disiplin, kraatif, inovatif, dinamis, profesional, dan berjiwa kejuangan Sedarmayanti, 2009 dalam jurnal (Hambalin, 2013: 80). Produktifitas kerja bukan semata-mata ditunjukan untuk mendapatkan hasil kerja yang lebih banyak, melainkan untuk mendapatkan kualitas dalam melakukan suatu pekerjaan.

Berkaitan dengan uraian diatas, maka peneliti mengambil judul tentang Pengaruh Pelatihan dan Kalimat Motivasi terhadap Produktifitas Kerja Karyawan UMKM.

\section{METODE PENELITIAN}

\section{Lokasi Penelitian}

Lokasi penelitian yang peneliti ambil adalah UMKM pembuatan kaos dan jaket milik Pak Ahmad Zainuri yang beralamat di Jl.Tlogomas NO1. RT 06/RW 07 dikecamatan Lowokwaru Kota Malang Jawa Timur. Kepada 
Bapak Ahmad Zainuri peneliti Malang. Jawa Timur. mengucapkan terima kasih yang sebesarnya karena telah diijinkan melaksanakan penelitian ini.

Alasan peneliti memilih tempat ini dikarenakan fashion dan trend yang berkembang pesat, serta UMKM ini merupakan usaha yang memproduksi barang yang berupa kaos atau jaket. Kaos dan jaket tersebut telah dijual diberbagai daerah yang menjadi andalan pemiliknya. Kaos dan jaket yang dibuat adalah rancangan pemesan dan dibuat sesuai dengan rancangan yang harapkan oleh pemesan. Dengan demikian usaha ini tetap eksis walaupun karyawan yang bekerja di tempat ini sedikit tetapi usaha ini mampu bersaing dengan usaha-usaha lain yang memproduksi kaos dan jaket . UMKM ini juga memperhatikan model kaos dan jaket sesuai zaman sekarang sehingga dapat menarik minat pelangan yang memesan.

\section{Waktu Penelitian}

Waktu penelitian merupakan waktu dimana penelitian akan memulai penelitian. Penelitian akan dilakukan pada tanggal 25 November sampai dengan 25 Desember. Penelitian ini dilakukan di UMKM NESS di Jl.raya Tlogomas No.1 RT 06 RW 07. Kota 
masalah yang dibawa oleh peneliti setelah memasuki penelitian berkembang yaitu memperluas atau memperdalam masalah yang telah disiapkan. Dengan demikian tidak akan merubah judul dalam penelitian, sehingga judul penelitian cukup disempurnakan. Yang ketiga adalah masalah yang dibawa oleh peneliti setelah masuk kedalam lingkungan penelitian berubah total, sehingga harus ganti masalah (Sugiyono, 2011:205).

\section{Sumber Data}

Guna memproleh data yang valid dan dapat dipertangungjawabkan secara obyektif, dalam penelitian ini sumber data yang di proleh adalah primer dan data sekunder :

a) Data primer

Data primer adalah data asli yang didapat sendiri oleh peneliti untuk menjawab penelitiannya secara khusus, dan data ini tidak tersedia sehingga peneliti harus melakukan penelitian atau pengadaan data sendiri, dan data diproleh dari sumbernya (Istijanto, 2005-32). Data primer didapat secara lansung kepada seseorang yang menjadi responden dalam penelitian minsalnya wawancara, kusioner, observasi dan lain sebagainya.

\section{b) Data sekunder}

Sumber data sekunder merupakan data yang didapat tidak langsung memberikan data kepada pengumpul data (Sugiyono,2008 :402). Data yang didapat secara tidak langsung yang didapatkan dari data atau arsip yang dimiliki oleh perusahaan dan sumbersumber yang terkait lainnya, seperti literatur, buku, serta jurnal. Data sekunder merupakan struktur data masa lalu yang telah dikumpulkan dan dihimpun sebelumnya oleh pihak terkait.

\section{Teknik Pengumpulan Data}

Menurut Sugiyono (2011:p224) teknik pengumpulan data adalah suatu langkah yang paling strategis dalam penelitian, karena tujuan utama dari penelitian adalah mendapatkan data. Tanpa mengetahui cara pengumpulan data, maka peneliti tidak akan mendapatkan data yang sesuai dengan standar yang telah ada.. Dalam kegiatan penelitian ini penulis mengunakan beberapa teknik pengumpulan data, antara lain sebagai berikut :

a) Observasi 
.Observasi dilakukan untuk analisis interprestasi data. Dalam mendekatkan peneliti kepada seseorang yang akan ditelitinya dan situasi maupun lingkungan mereka yang sebenarnya. Peneliti dapat masuk ke lingkungan yang ditelitinya atau yang dikenal dengan observasi partisipatif (Sugiyono, 2011: 226).

b) Interview (wawancara)

Wawancara adalah suatu percakapan yang dilakukan oleh dua pihak yaitu pewawancara (interviewer) yang mengajukan pertanyaan dan terwawancara (interviewee) yang memberikan jawaban atas pertanyaan yang ditanyakan (Moleong, 2012:118).

c) Dokumentasi

Dokumentasi adalah metode pengumpulan data yang datanya diproleh dari buku, internet, atau dokumen lain yang dapat menunjang penelitian yang dilakukan. Dokumntasi adalah cacatan mengenain peristiwa yang sudah berlalu, peneliti mengumpulkan dokumen yang dapat berupa tulisan, gambar, atau karyakarya dari seseorang (Sugiyono, 2012: 240).

\section{Keabsahan Data}

Penilaian keabsahan penelitian ini dalam penelitian kualitatif dapat terjadi suatu proses pengumpulan data dan

penelitian ini peneliti mengunakan teknik Triangulasi. Triangulasi adalah cara pemeriksaan data yang memanfaatkan sesuatu yang lain (Moleong, 2009:330).

Dalam penelitian ini peneliti mengunakan teknik triangulasi sumber yaitu dengan cara membandigkan atau mengecek balik derajat kepercayaan suatu informasi yang satu dengan yang lainnya. Menurut Sugiyono (2011:273) ada tiga macam triangulasi. Pertama yaitu triangulasi sumber untuk menguji kredibilitas data yang dilakukan dengan cara mengecek data yang telah diproleh melalui berbagai macam sumber. Kedua yaitu triangulasi teknik untuk menguji kredibilitas dan dilakukan dengan cara mengecek data kepada sumber yang sama dengan teknik yang berbeda. Ketiga adalah triangulasi waktu data yang dikumpulkan dengan teknik wawancara yang dilakukan oleh peneliti pada saat di pagi hari biasanya data lebih valid. Untuk itu harus di uji lagi kredibilitas data dengan mengecek kembali di waktu yang berbeda. Jika hasil uji menghasilkan data yang berbeda, maka dilakukan secara berulang-ulang sehingga sampai ditemukan hasil data yang valid.

\section{Analisis Data}


Analisis data adalah suatu proses mencari dan menyusun secara teratur data yang telah di dapatkan dari hasil wawancara, catatan lapangan, dan dokumentasi dengan cara mengorganisasikan data kedalam katagori, menjabarkan ke dalam unit-unit, melakukan proses akhir, menyusun dalam pola memilih mana yang penting dan yang akan dipelajari, dan membuat kesimpulan sehingga mudah difahami oleh diri sendiri maupun orang lain.

Dalam analisis data ada beberapa alur kegiatan dalam penelitian yaitu :

a. Reduksi data, adalah data yang diproleh dilapangan akan direduksi atau merangkum memilih-milih hal yang pokok, memfokuskan pada halhal yang yang penting, dicari tema dan polanyadan membuang yang tidak perlu. Dengan demikian data yang telah di reduksi akan memberikan gambaran yang lebih jelas, sehingga mempermudah peneliti untuk melakukan pengumpulan data yang diperlukan.

b. Penyajian data, adalah penyajian data yang dapat dilakukan dalam bentuk tabel, grafik, phie chard, pictogram dan sejenisnya, maka data yang diproleh dapat terorganisasikan tersusun dalam pola sehingga mempermudah difahami oleh peneliti.

c. Penarikan kesimpulan adalah setelah data dikumpulkan dan dianalisis maka kesimpulan yang dikemukankan merupakan kesimpulan yang kredibel. (sugiyono 2012:p426-438)

\section{HASIL DAN PEMBAHASAN}

\section{Sejarah UMKM}

Umkm ini berdiri pada tahun 1989 sampai sekarang masih eksis di kota malang yang kurang lebih sudah 27 tahun.UMKM ini berfokus kepada pembuatan kaos,jaket,celana dan lain sebagainya yang langsung di pesan oleh konsumen. Dari informasi yang peneliti dapat secara langsung dari pemiliknya, mengatakan bahwa pemilik UMKM ini pernah kerja dengan orang dan pada akhirnya ada perasaan jenuh terhadap pekerjaan di tempat ia bekerja dengan alasan tidak ingin di atur dan diperintah oleh orang lain, sehingga pemiliki mencoba membuka usaha ini dengan tekat yang kuat dan komitmen, sehingga dapat membuka usaha ini dengan bermodalkan uang muka dari konsumen yang memesan baju. Sebelumnya pemilik adalah seorang pemain sepak bola, dari itu ia berinisiatif untuk membuka usaha 
ini agar dapat membuat kostum pemain atau kostum dalam timnya. Selain itu harapan pemilik membuka usaha ini adalah untuk menambah uang tambahan untuk kebutruhan sehari-hari dan dengan berjalannya waktu UMKM ini terus berkembang sehingga menciptakan lapagan pekerjaan yang dapat membantu mengurangi angka penganguran khususnya di kota malang dan samapi saat ini memiliki karyawan 5 orang.

\section{Hasil Pengaruh Pelatihan}

\section{a. Sistem Pelatihan yang \\ Dilaksanakan}

Strauss dan Sayles (1982:405) menjelaskan, efisiensi organisasi manapunn tergantung secara langsung pada bagaimana baiknya para karyawan dilatih. Karyawan yang baru bekerja biaasanya sangat memerlukan pelatihan sebelum mereka memulai pekerjaan mereka. Karyawan yang lebih tua memerlukan pelatihan agar lebih siap dalam menghadapi tuntutan suatu pekerjaan saat ini dan harus mempersiapkan diri untuk pemindahan dan kenaikan jabatan.

Sedangkan menurut Mangkuprawira (2002:135) berpendapat bahwa pelatihan merupakan suatu proses mengajarkan pengetahuan dan keahlian tertentu serta sikap agar seseorang semakin terampil dan mampu dalam melaksanakan tanggung jawab yang telah diberikan kepada seseorang sesuai dengan standar yang telah diberikan oleh perusahaan maupun organisasi tersebut.

Penjelasan di atas diperkuat dengan teori dari Kaswan (2011) yaitu, pelatihan adalah suatu proses meningkatkan pengetahuan dan keterampilan karyawan. Pelatihan juga meliputi perubahan sikap sehingga karyawan dapat melaksanakan pekerjaan dengan baik dan sesuai dengan apa yang telah diharapkan oleh perusahaan maupun organisasi. Pelatihan merupakan suatu proses yang meliputi serangkaian upaya yang dilakukan dengan sengaja dalam bentuk pemberian bantuan kepada karyawan yang dilakukan oleh seseorang yang memiliki keahlian dalam bidangnya dalam satuan waktu yang bertujuan agar dapat meningkatkan keahlian karyawan dalam melaksanakan pekerjaan dalam bidang tertentu untuk meningkatkan efektivitas dan produktivitas dalam suatu perusahaan maupun organisasi.

\section{b. Materi pelatihan}

Materi yang diberikan dalam suatu pelatihan harus sesuai dengan kebutuhan sehingga dapat digunkan dalam menyelesaikan pekerjaan karyawan, selain itu materi yang disampaikan harus 
runtut dan sistematis. Materi pelatihan yang diberikan oleh pemilik UMKM cukup lah simple yaitu materi tentang bagaimana cara menyablon baju, dan menjahit baju dengan baik dann benar.

\section{c. Kesesuaian Pelatihan terhadap Kerja yang Ditekuni}

Dari data yang diproleh rata-rata karyawan memberikan tangapan yang hampir sama karena pelatihan yang diberikan sebelum bekerja sangat sesuai dengan pekerjaan yang telah ditekuni selama ini.

\section{d. Manfaat Pelatihan}

Pelatihan yang baik juga akan membawa manfaat seperti yang telah dikemukankan oleh Neo, Hollenbeck, Gerhart, Wright dikutif di jurnal Agusta dan Sutanto Vol. 1, No. 3, (2013) yaitu: pelatihan dapat meningkatkan pengetahuan para karyawan atas budaya dan para pesaing luar, dapat membantu karyawan yang memiliki keterampilan untuk bekerja dengn teknologi baru, membantu karyawan untuk mengerti bagaimana bekerja secara efektif dalam tim untuk menghasilakan jasa dan produk yang berkualitas, memastikan bahwa budaya perusahaan menerapkan akan inovasi, kreativitas dan pembelajaran, menjamin keselamatan dengan memberikan cara-cara baru bagi karyawan agar dapat memberikan kontribusi bagi perusahaan pada saat pekerjaan dan kepentingan mereka berubah atau pada saat kemampuan mereka menjadi absolut, mempersiapkan karyawan untuk menerima dan bekerja secara lebih efektif satu sama lain, terutama kaum minoritas dan para wanita (Neo et al. 2008-266).

Dan di perkuat oleh teori sikula (1976) yang dikutip oleh Munandar (1978) dan dikutip kembali oleh Moh. As'ad (1987:75) tentang tujuan dari pelatihan yaitu :

a) Meningkatkan produktivitas kerja Dengan adanya pelatihan dapat meningkatkan prestasi kerja pada posisijabatan saat ini.

b) Meningkatkan mutu kerja

Dalam meningkatkan baik kualitas maupun kuantitas, seseorang karyawan yang memiliki kualitas kerja yang tinggi dan akan lebih sedikit berbuat kesalahan dalam pekerjaannya.

c) Meningkatkan ketepatan dalam perencanaan sumberdaya manusia Suatu pelatihan dikatakan baik jika dapat mempersiapkan tenaga kerja untuk keperluan dimasa yang akan datang.

d) Meningkatkan moral kerja 
Jika suatu perusahaan dapat dan administrasi perusahaan. Dalam hal melaksanakan program pelatihan ini Hygiene Factors disebut juga motivasi yang tepat maka iklim dan suasan organisasi pada umumnya akan menjadi lebih baik. Dengan danya iklim kerja yang baik maka moral kerja (semangat kerja) juga dapat meningkat.

e) Menjaga kesehatan dan keselamatan kerja

Suartu pelatihan dapat dikatakan bisa membantu menghindari dari hal-hal yang tidak diinginkan seperti timbulnya kecelakaan-kecelakaan kerja.

f) Menunjang pertumbuhan pribadi

Suatu program yang tepat
sebenarnya adalah yang
memberikan keuntungan bagi kedua
belah pihak,baik karyawan maupun
perusahaan itu sendiri. Bagi
karyawan akan menambah
pengalaman,keahlian,dam
intelektual.

\section{Pengaruh Kalimat Motivasi}

Menurut Herzberg mengatakan ada beberapa yang menjadi faktor motivasi yaitu, (1) Hygiene Factors yang meliputi, kondisi kerja, gaji, jaminan kerja, kehidupan pribadi, kualitas supervise, hubungan antar prbadi, kebijaksanaan Eksternal; (2) Motivation Factors yang berkaitan dengan isi pekerjaan mencakup keberhasilan, pekerjaan yang menantang, pengakuan, peningkatan dan pertumbuhan dalam pekerjaan. Motivation Factors disebut juga motivasi Internal.(koontz,1990:123)

Sedangkan menurut Sedarmayanti (2001:12) dalam jurnal Purnama (2008) yang berjudul Pengaruh motivasi kerja terhadap produktifitas kerja karyawan pada bagian produksi CV.EPSILON BANDUNG mengatakan ada beberapa faktor yang mempengaruhui produktifitas kerja seseorang adalah sikap mental yang berupa motivasi kerja, disiplin, dan etika kerja, keahlian, manajemen hubungan industrial pancasila, kesehatan, jaminan sosial, lingkungan kerja, dan iklim kerja, sarana produksi, teknologi dan kesempatan dalam berprestasi.

Menurut Nawawi (2001) bahwa kata motivasi (motivation) kata dasarnya adalah motif (motive) yang berarti dorongan, sebab atau alasan seseorang melakukan sesuatu. Dengan demikian motivasi berarti suatu kondisi yang mendorong atau menjadikan sebab seseorang melakukan suatu 
perbuatan/kegiatan, yang berlangsung secara sadar.

Kalimat motivasi yang digunakan untuk mendorong seseorang melaksanakan pekerjaan dengan baik dapat memberikan dampak yang besar kepada hasil produksi. Dengan adanya pemberian pujian secara tidak telah mendorong seseorang secara psikologis bekerja lebih baik lagi dari sebelumnya. Kalimat motivasi sebenarnya bukan sekedar pujian tapi juga berupa kalimat perbandingan yang baik dimana posisi karyawan yang diberikan kalimat akan merasa lebih baik dari sebelumnya.

\section{Pembahasan}

Hasil dari penelitian yang telah di lakukan oleh peneliti dengan mewawancarai setiap karyawan dapat dikatakan pelatihan dan motivasi yang telah diberikan oleh Pemilik usaha cukup baik.

Pelaksanaan pelatihaan yang telah diterapkan oleh Pemilik UMKM NESS Tailor dan Konveksi cukup efektif karena hasil wawancara kepada setiap karyawan mengatakan pelatihan yang telah diberikan oleh pemilik usaha tidak terlalu rumit dan materi yang disampaikan cukup dimengerti sehingga karyawan bisa langsung dapat praktik dalam pelatihan yang telah dilakaukan.

Dalam pelaksanaan pelatihan dikatakan cukup baik, karena pemilik hanya sedikip memberikan materi kepada setiap karyawan dan karyawan disuruh melihat terlebih dahulu apa yang telah dipraktikan oleh pemilik sehingga pelatihan yang dilakukan tidak sia-sia dan karyawan langsung disuruh untuk parktik sehingga karyawan dapat dengan mudah memahami dan langsung bisa dalam melakukan pekerjaan yang telah diberikan setelah pelatihan.

Demikian pula dengan motivasi yang ada di UMKM NESS Tailor dan Konveksi cukup baik dalam meningkatkan produktifitas kerja karyawan dilihat dari hasil wawancara yang telah dilakukan oleh peneliti kepada karyawan, seperti upah yang telah diberikan oleh pemilik usaha sudah cukup baik dikarenakan sistem pengupahan sesuai dengan jam kerja setiap karyaawan dan upah yang telah diberikan cukup untuk kebutuhan setiap karyawan.

Dari hasil penelitiaan yang telah dilakukan tentang pelatihan dan motivasi yang telah diterapkan oleh pemilik Usaha kepada karyawan diharapkan mampu menjalankan tugas dan pekerjaan mereka 
dengan baik dan dapat meningkatkan produktifitas kerja karyawan.

\section{KESIMPULAN}

Berdasarkan hasil dan kajian teori dari penelitian ini maka dapat disimpulkan, bahwa:

1. Pelatihan yang diberikan oleh pemilik usaha seperti pelatihan tentang menyablon baju dan menjahit berpengaruh positif terhadap produktifitas kerja karyawan dikarenakan dengan adanya pelatihan yang diberikan kepada para karyawan mampu menyelesaikan pekerjaan dengan baik dan bermanfaat bagi setiap karyawan bekerja di usaha ini.

2. Kalimat motivasi yang telah diberikan pemilik kepada setiap karyawan berpengaruh positif terhadap produktifitas kerja karyawan dilihat dari segi produktivitas hasil kerja karyawan dan semangat kerja karyawan.

\section{KEPUSTAKAAN}

Agusta dan Sutanto. 2013. "Pengaruh pelatihan dan motivasi kerja terhadap kinerja karyawan CV Haragon Surabaya" Jurnal Program Studi Manajemen, Vol 1 No. 3

Budiartha, Bagia dan Wayan. 2015. pengaruh pelatihan dan motivasi kerja terhadap produktivitas kerja karyawan. e-Journal Bisma Universitas Pendidikan Ganesha Jurusan Manajemen Volume 3 Tahun
2015.

Istijanto. 2005. Riset Sumber Daya Manusia. Jakarta: Gramedia Pustaka Utama.

Moleong. 2009. Metodologi Penelitian Kualitatif Edisi Revisi. Bandung: Remaja Rosdakarya.

Satria, Kuswara. 2013. "Pengaruh Motivasi dan Pelatihan terhadap Kompetensi Kerja Serta Implikasinya pada Produktivitas Pegawai Dinas Perhubungan Kota Bandung" Jurnal Ekonomi, Bisnis \& Entrepreneurship Vol. 7 No. 2

Strauss dan Sayles. 1982. Manajemen Personalia Segi Manusia dalam organisasi. Jakarta: Sapdodadi.

Sudaryanto dan Hanim,Anifatul. 2002. "Evaluasi Kesiapan UKM Menyongsong Pasar Bebas Asean (AFTA): Analisis Perspektif dan Tinjauan Teoritis" Jurnal Ekonomi Akuntansi dan Manajemen, Vol 1 No 2.

Sugiyono. 2011. Metode Penelitian Kuantitatif, kualitatif dan $R \& D$. Bandung: Alfabeta.

Sugiyono. 2012. Metode Penelitian Bisnis. Bandung: Alfabeta.

Sunarto. 2005. Manajemen Karyawan. Yogyakarta: Aditya Media.

Suwatno dan Priansa. 2014. Manajemen SDM dalam Organisasi Publik dan Bisnis. Bandung: Alfabeta.

https://www.google.co.id/search?q=peng ertian+karyawan+menurut+para+ahli + pdf\&oq=pengertian + karyawan $+\& g$ s_l=serp.1.5.0110.66614.66614.0.693 $\underline{69.1 .1 .0 .0 .0 .0 .195 .195 .0 \mathrm{j} 1.1 .0 \ldots . .0 \ldots 1}$ c.1.64.serp..0.1.193.8TfNlE-7Mr8 diakses pada tgl 08 November 2016. http://wwtarajatim.com/lihat/berita/1425 39/pemprov-jatim-lakukan-langkahstrategis- hadapi-mea diakses pada tgl 06 November 2016.

http://repository.usu.ac.id/bitstream/1234 56789/18681/4/Chapter\%20II.pdf diakses pada 17 Desember 2016. 